\author{
Jurnal E-KOMTEK (Elektro-Komputer-Teknik) \\ Vol. 4 No. 1 (2020) pp. 48-61 \\ https://jurnal.politeknik-kebumen.ac.id/index.php/E-KOMTEK \\ p-ISSN : 2580-3719 e-ISSN : 2622-3066
}

\title{
Kajian Antarmuka dan Evaluasi Layanan pada Website Program Studi X Menggunakan Kansei Engineering Dan Metode Kano
}

\author{
Seliwati Ginting ${ }^{1 *}$, Ana Hadiana ${ }^{2}$ \\ ${ }^{1}$ Manajemen Informatika, Politeknik Piksi Ganesha Bandung, Bandung, Indonesia, 40274 \\ ${ }^{2}$ Lembaga Ilmu Pengetahuan Indonesia, Bandung, Indonesia, 40135 \\ *E-mail : seliwati88@gmail.com \\ Doi $\quad$ : https://doi.org/10.37339/e-komtek.v4i1.233
}

Diterbitkan oleh Politeknik Dharma Patria Kebumen

\section{Info Artikel \\ Diterima : \\ 02-06-2020 \\ Diperbaiki : \\ 12-06-2020 \\ Disetujui : \\ 17-06-2020}

\begin{abstract}
ABSTRAK
Tujuan dari penelitian ini adalah membuat rekomendasi elemen apa saja dalam merancang atau memperbaiki website mahasiswa berdasarakan kansei enginnering dan layanan-layanan yang perlu ditingkatkan pada website prodi X. Dalam memenuhinya dapat memanfaatkan rekayasa kansei untuk menganalisis desain website yang menterjemahkan perasaan stakeholder kedalam desain website dan metode kano untuk evaluasi layanan website. Data didapatkan menggunakan kuisioner terhadap 30 responden. Hasil kuisioner diolah menggunakan statistik multivariate, dan evaluasi layanan menggunakan Metode Kano. Faktor utama yang berpengaruh dalam tampilan website yaitu "segar", artinya desain website dibuat sesuai selera anak muda dan keren seperti warna background, tidak membutuhkan header menu dan lain-lain. Sedangan untuk evaluasi layanan menghasilkan 10 atribut yang harus ditingkatkan sesuai dengan derajat prioritas, misalnya pada dimensi usability, webiste lebih mudah dioperasikan. Selain itu, ada layanan yang dipertahankan sesuai dengan derajat prioritas sebanyak 15 atribut.
\end{abstract}

Kata Kunci: User Interface; Rekayasa Kansei; Layanan; Metode Kano

\begin{abstract}
The purpose of this study is to make recommendations on what elements are in designing or improving student websites based on Kansei Engineering and services that need to be improved on the Study Program X website. In fulfilling them can utilize Kansei engineering to analyze website design that translates stakeholder feelings into website design and methods canoe for website service evaluation. Data obtained using a questionnaire of 30 respondents. The results of the questionnaire were processed using multivariate statistics, and service evaluation using the Kano Method. The main factor that influences the appearance of the website is "fresh", meaning that the website design is made according to the tastes of young people and cool like the background color, does not require a header menu and others. Whereas for service evaluation it produces 10 attributes that must be improved according to the priority level, for example in the usability dimension, the website is easier to operate. In addition, there are services that are maintained in accordance with the priority degrees of 15 attributes.

Keywords: User Interface; Kansei Engineering; Service; Kano Method
\end{abstract}

Alamat Korespondensi : Jl. Letnan Jenderal Suprapto No.73 Kebumen, Jawa Tengah, Indonesia 55431 This work is licensed under a Creative Commons Attribution-NonCommercial 4.0 International License. 


\section{PENDAHULUAN}

Website mahasiswa seharusnya memberikan pelayanan yang dibutuhkan mahasiswa dan dosen. Pelayanan dapat berupa berita-berita yang terbaru di jurusan dan kegiatan-kegiatan jurusan yang ter-update [1]. Kebanyakan Program studi telah memiliki website mahasiswa untuk membagikan informasi jurusan terhadap mahasiwanya. Akan tetapi pengunjung website tersebut kurang. Hal ini terlihat dari rekap pengunjung pada website Program Studi (PRODI) X sebanyak 299 pengunjung selama 2 bulan, datanya dapat dilihat pada Gambar 1, jika dirata-rata pengunjung per harinya sebanyak 4-5 orang, jumlah pengunjung website mahasiswa sebanyak ini dapat dikategorikan kurang diminati. Kekurangan lain dari website ini yaitu layanan informasi yang diberikan. Pada tahun 2018 jumlah berita yang tayangkan hanya 1 berita dan tahun 2019 sebanyak 7 berita. Hal ini memperlihatkan kurangnya pelayanan informasi yang diberikan website terhadap mahasiswa atau pihak lainnya. Rekapitulasi pengunjung websait Prodi X disajikan pada Gambar 1 [1], [2].

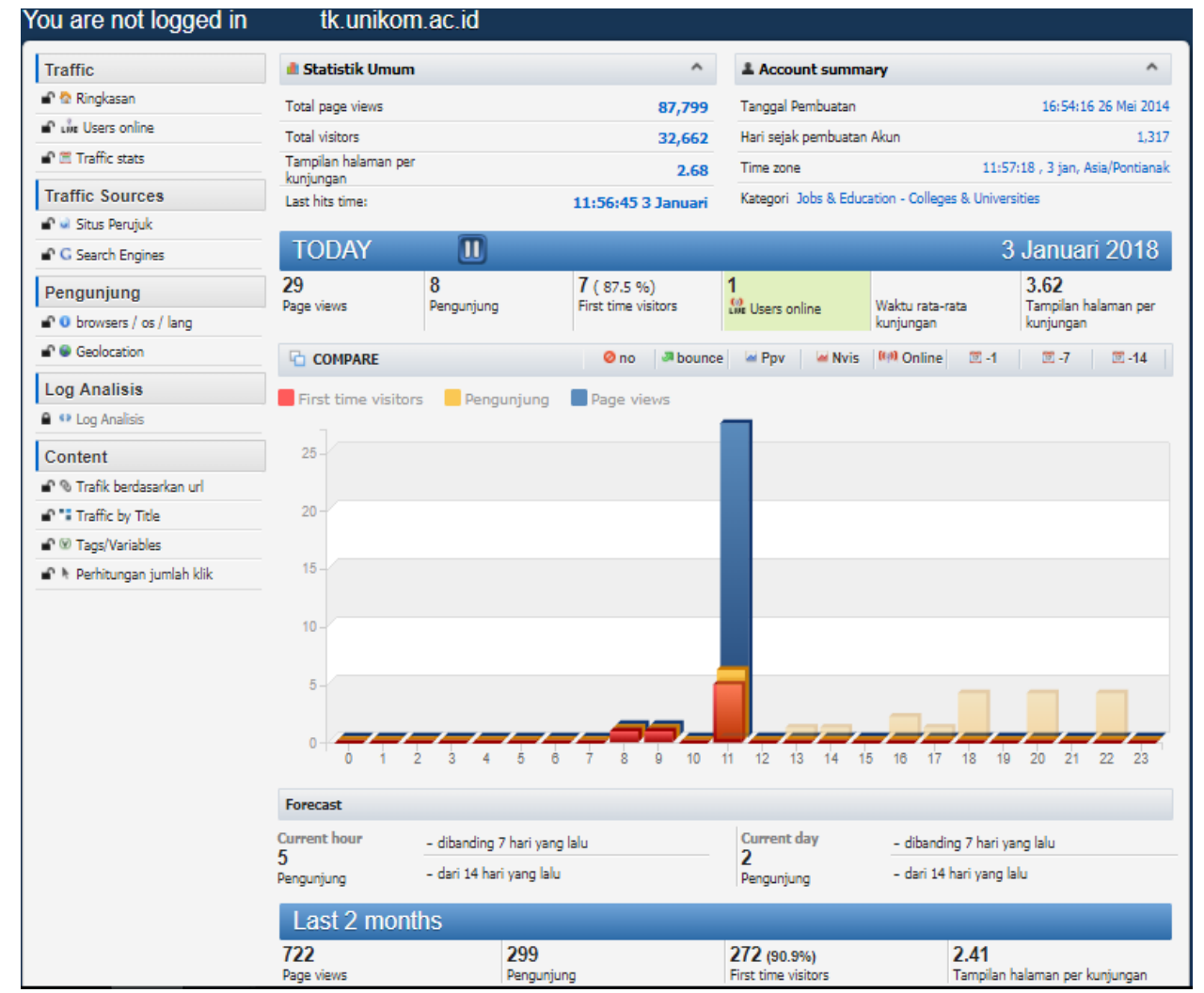

Gambar 1. Rekapitulasi Pengujung Website Prodi X

Selain dari jumlah pengunjung dan jumlah informasi yang ditampilkan pada website. Desain tampilan website dikembangkan dengan dasar fungsi dan kegunaan. Pada 
perkembangannya proses pembuatan desain tampilan sebuah website agar dapat dimanfaatan ketika telah di-release mulai melibatkan sisi perasaan pengguna [2], [3].

Oleh karena itu dibutuhkan analisis terhadap antarmuka dan layanan untuk mendapatkan rekomendasi perbaikan-perbaikan baik segi antarmuka dan layanan pada website untuk menarik pengunjung. Hal ini dapat dilakukan dengan menerapkan Kansei Engineering untuk analisis antarmuka website dan metode kano untuk analisis layanan-layanan [8], [9].

Tujuan dari penelitian yang dilakukan adalah membuat rekomendasi elemen apa saja dalam merancang atau memperbaiki website mahasiswa berdasarakan kansei enginnering dan layanan-layanan yang perlu ditingkatkan pada website prodi X.

\section{MATERIAL DAN METODE}

\subsection{Material}

\section{a. Kansei Engineering}

Kansei Engineering atau Kansei Engineering telah digunakan untuk desain kansei untuk beragam produk di seluruh dunia, Kansei Engineering merupakan teknologi yang memungkinkan penggabungan emosi manusia dalam persyaratan desain. Memiliki perspektif bahwa kansei sifatnya unik untuk berbagai domain yang berbeda dan juga unik untuk kelompok sasaran pengguna yang berbeda, dan menggunakan instrumen pengukuran verbal dalam metodologinya [3].

Kansei Engineering merupakan terobosan yang menghubungkan emosional/afektif dengan teknologi agar dapat dimanipulasi untuk menciptakan website pada kasus penelitian ini yang disesuaikan dengan emosional/perasaan stakeholder. Kansei Engineering adalah kemajuan IT dalam bidang ergonomi yang menyesuaikan dengan pandangan stakeholder dalam menciptakan, memperbaiki produk termasuk software [4].

Tahapan Kansei Engineering adalah sebagai berikut [5], [6]:

1) Dalam tahapan awal dari Kansei Engineering, konsumen akan diinvestigasi menggunakan metode psikologis atau psiko-fisiologis.

2) Fakta yang dikumpulkan akan dianalisis menggunakan analisis multivariat.

3) Dengan Kansei Engineering fakta yang dikaji akan diterjemahkan menjadi desain produk (website) 
Alur Kansei Engineering dengan KEPack disajikan pada Gambar 2.

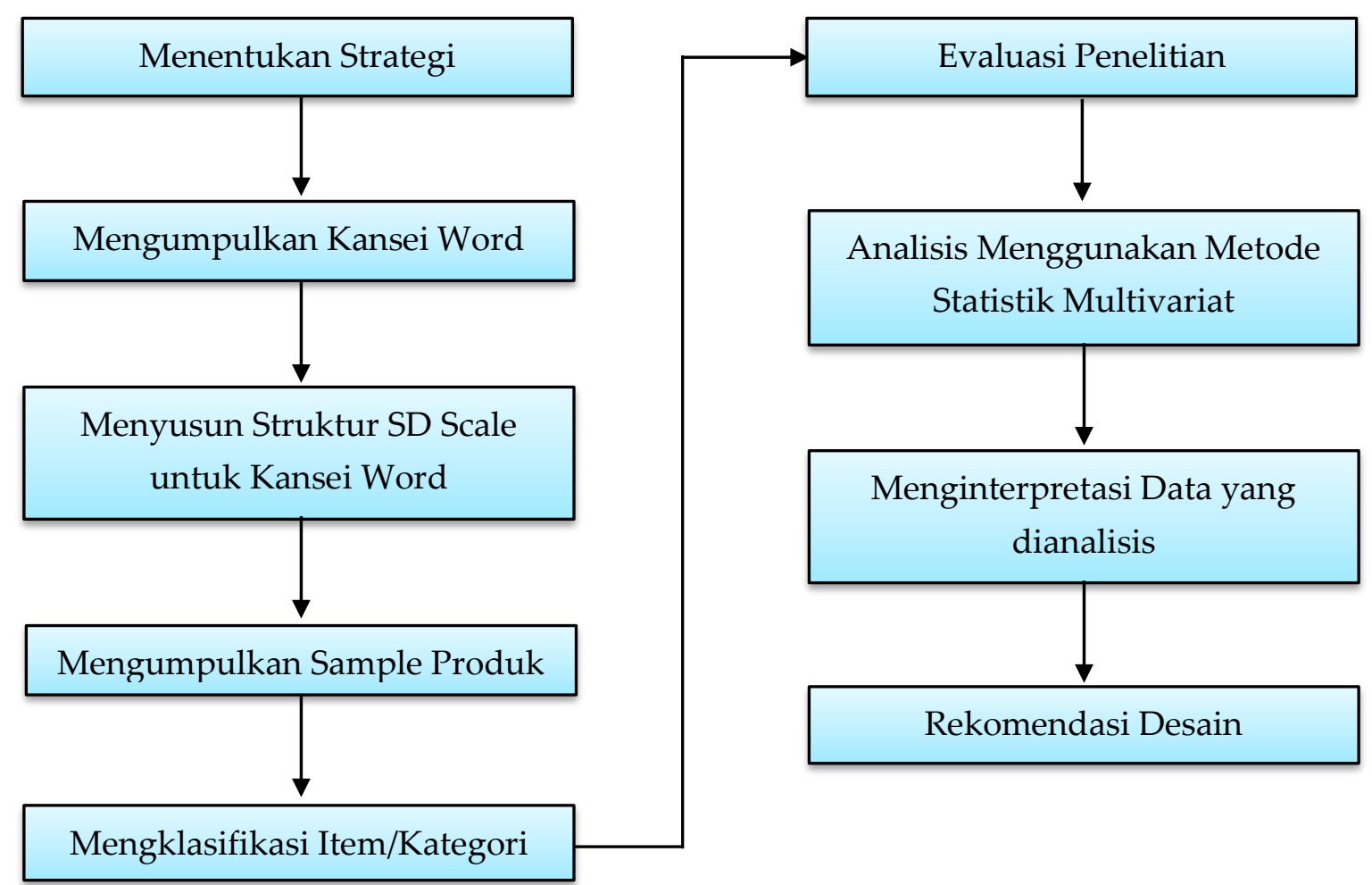

Gambar 2. Alur Kansei Engineering dengan KEPack

Pada dunia industri, kriteria afektif/emosional menjadi hal yang diperlukan dalam membuat konsep suatu produk. Biarpun produk dikonsep, dibangun dan diuji sebagus mungkin tidak akan bermanfaat, apabila produknya tidak disukai oleh stakeholder. Selain itu stakeholder sukar dalam mencurahkan kemauannya atau emosionalnya [7].

\section{b. Metode Kano}

Metode kano merupakan cara dalam mengeluarakan produk atau layanan yang berkualitas. Dilihat dari definisi tersebut, dapat diasumsikan bahwa metode ini dapat dimanfaatkan untuk menaikan nilai produk atau layanan berlandasan pandangan stakeholder [8].

Berikut adalah langkah-langkah dalam menggunakan metode kano [9]:

1) Mengidentifikasi fitur-fitur penelitian

2) Membangun dan melaksanakan survei terhadap pelanggan

3) Menganalisis tanggapan hasil survei

4) Membuat prioritas aksi yang berdasarkan hasil temuan survei

Langkah metode kano disajikan pada Gambar 3, sedangkan diagram kano disajikan pada Gambar 4. 


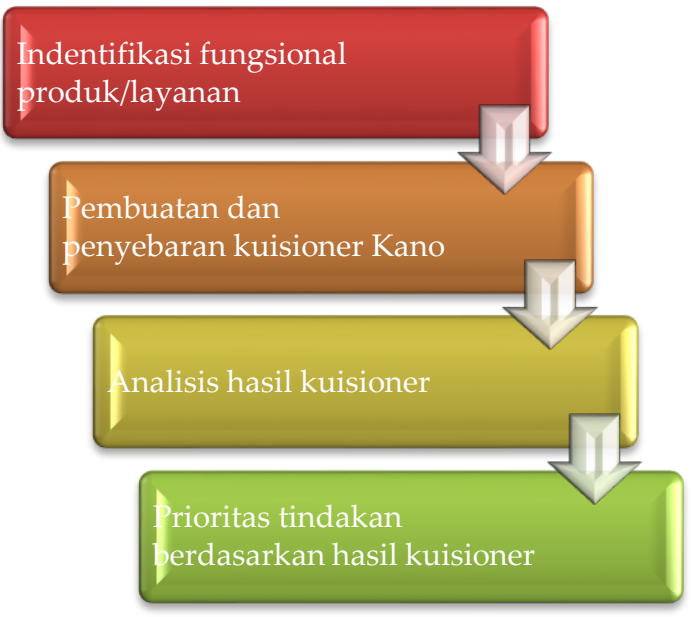

Gambar 3. Langkah Metode Kano

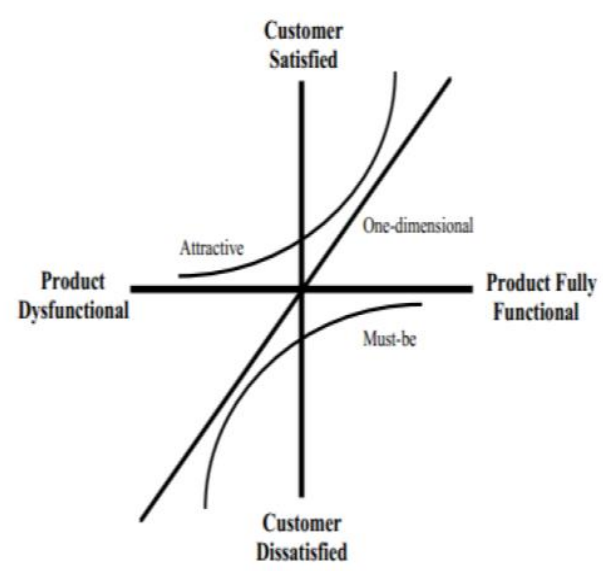

Gambar 4. Diagram Kano

\section{c. Penelitian Terkait}

Dalam pelaksanaan penelitian ini dapat berjalan dengan ada bantuan dari penelitianpenelitian dari peneliti yang berkaitan. Sehingga pembanding untuk mendapatkan pembeda antara penelitian yang dilakukan dengan penelitian yang lain yaitu mengenai mendesain website yang menggunakan kansei engineering dan evaluasi layanan dengan metode kano. Perbandingan peneliti terdahulu dan sekarang disajikan pada Tabel 1.

Tabel 1. Perbandingan Peneliti Terdahulu dan Sekarang

\begin{tabular}{|c|c|c|c|c|}
\hline \multirow{2}{*}{ Nama Penulis, Tahun dan Judul } & \multirow{2}{*}{ Keluaran } & \multirow{2}{*}{ Kesesuaian } & \multicolumn{2}{|c|}{ Variasi } \\
\hline & & & Terdahulu & Rencana Penelitian \\
\hline $\begin{array}{l}\text { Yudhi Raymond Ramadhan, } 2016 \\
\text { Implementasi Kansei Engineering } \\
\text { Dalam Desain } \\
\text { Tampilan Website Perguruan } \\
\text { Tinggi (Studi Kasus : STIEB } \\
\text { Perdana Mandiri Purwakarta) [5]. }\end{array}$ & $\begin{array}{l}\text { Menghasilkan } \\
\text { rekomendasi desain }\end{array}$ & $\begin{array}{l}\text { Analisis data } \\
\text { menggunakan } \\
\text { multivariat }\end{array}$ & $\begin{array}{l}\text { Analisis } \\
\text { Tampilan desain } \\
\text { pada dunia } \\
\text { pendidikan }\end{array}$ & $\begin{array}{l}\text { Menganalisis layanan } \\
\text { website jurusan } \\
\text { menggunakan } \\
\text { metode kano }\end{array}$ \\
\hline $\begin{array}{l}\text { Freedy Wicaksono, } 2016 \\
\text { Penerapan Kansei Engineerung } \\
\text { pada Rancangan Antarmuka E- } \\
\text { Learning Berbasis Website [6] }\end{array}$ & $\begin{array}{l}\text { Matriks usulan } \\
\text { tampilan atau } \\
\text { prototype produk }\end{array}$ & $\begin{array}{l}\text { Menggunakan } \\
\text { Kansei Engineering } \\
\text { dalam } \\
\text { membangun } \\
\text { website }\end{array}$ & $\begin{array}{l}\text { Desain } \\
\text { antarmuka } \\
\text { untuk Profile E- } \\
\text { Learning }\end{array}$ & $\begin{array}{l}\text { Rekomendasi desain } \\
\text { website mahasiswa }\end{array}$ \\
\hline $\begin{array}{l}\text { Muhamad Nurdin Abdul } \\
\text { Muhaemin, 2016, Implementasi } \\
\text { Kansei Engineering dalam Desain } \\
\text { Website Profile Perguruan Tinggi } \\
\text { [7]. }\end{array}$ & $\begin{array}{l}\text { Dua konsep emosi } \\
\text { yang menggandung } \\
6 \text { emosi elemen- } \\
\text { elemen desain. }\end{array}$ & $\begin{array}{l}\text { Menggunakan } \\
\text { Kansei Engineering } \\
\text { dalam } \\
\text { membangun } \\
\text { website }\end{array}$ & $\begin{array}{l}\text { Desain } \\
\text { antarmuka } \\
\text { untuk Profile } \\
\text { Perguruan } \\
\text { Tinggi }\end{array}$ & $\begin{array}{l}\text { Rekomendasi desain } \\
\text { website mahasiswa }\end{array}$ \\
\hline $\begin{array}{l}\text { Irsan Jaelani } \\
\text { Penerapan Metode Kano } \\
\text { Berdimensi Serqual dalam } \\
\text { Menganalisis Kualiats Layanan } \\
\text { Sistem Informasi Akademik } \\
\text { Terhadap Kepuasan Pengguna } \\
\text { (Studi Kasus SIMAK STT. } \\
\text { Wastukancana) [8]. }\end{array}$ & $\begin{array}{l}\text { Prioritas atribut } \\
\text { layanan yang mana } \\
\text { seharusnya } \\
\text { ditingkatkan atau } \\
\text { dipertahankan }\end{array}$ & $\begin{array}{l}\text { Menggunakan } \\
\text { metode kano. } \\
\text { Menganalisis } \\
\text { layanan website } \\
\text { pada dunia } \\
\text { akademik }\end{array}$ & $\begin{array}{l}\text { Selain } \\
\text { menganalisis } \\
\text { layanan website } \\
\text { ditambah } \\
\text { dengan analisis } \\
\text { desain website }\end{array}$ & $\begin{array}{l}\text { Membuat } \\
\text { rekomendasi layanan } \\
\text { yang dapat } \\
\text { ditambahkan pada } \\
\text { website jurusan dan } \\
\text { menggunakan Model } \\
\text { Webqual } 4.0\end{array}$ \\
\hline
\end{tabular}




\subsection{Metode}

Metode pelaksanaan yang digunakan dalam menyelesaikan penelitian ini adalah sebagai berikut:

a. Kajian Pustaka

Metode ini digunakan untuk mendapatkan informasi yang berkaitan dengan penelitian yang dilakukan yang berasal dari buku, jurnal penelitian, internet

b. Pengamatan Lapangan

Metode ini dilakukan untuk mengumpulkan fakta dari lapangan, untuk mengetahui sejauh apa website yang telah ada di prodi tersebut, jika masih ada kekurangan perlu diadakan kajian lebih dalam untuk menindaklanjuti terhadap website.

c. Perancangan

Mencari contoh specimen yang sesuai dengan studi kasus, menentukan kata-kata yang mencerminkan specimen untuk menjadi kansei word dan menentukan atribut-atribut yang perlu dinilai pada website yang sesuai dengan webqual 4.0

d. Pengujian

Pengujian dilakukan dengan menyebarkan kuesioner terhadap responden (mahasiswa) yang berisi kansei word dan atribut-atribut yang ditentukan pada tahap sebelumnya

e. Analisis

Hasil kuesioner dikaji untuk mendapatkan tampilan yang diinginkan mahasiswa dan atribut-atribut yang perlu diperbaiki dan dipertahankan berdasarkan tingkatannya.

f. Dokumentasi

Menyusun jurnal sebagai dokumen penelitian.

\section{HASIL DAN PEMBAHASAN}

\subsection{Pembahasan}

\section{a. Daftar Kansei Engineering}

Pengumpulan kansei word dilakukan dengan literature, melihat ungkapan sering muncul pada desain web, website, makalah penelitian dan jurnal penelitian yang serupa. Hasil dari pengamatan ini kansei word yang terkumpul sebanyak 35 kandidat kansei word [6]. Setelah mengetahui makna dari masing-masing kandidat kansei word, proses selanjutnya adalah 
menyaring kansei word yang akan digunakan. Proses penyaringan ini dilakukan dengan diskusi dengan ahli pada bidangnya. Daftar kansei engineering disajikan pada Tabel 2.

Tabel 2. Daftar Kansei Engineering

\begin{tabular}{cccccccc}
\hline No & Kansei Word & No & Kansei Word & No & Kansei Word & No & Kansei Word \\
\hline $\mathbf{1}$ & Aman & 6 & Informatif & 11 & Segar & 16 & Rumit \\
$\mathbf{2}$ & Serasi & 7 & Berkesan & 12 & Unik & 17 & Mewah \\
$\mathbf{3}$ & Kreatif & 8 & Cerah & 13 & Modern & 18 & Dinamis \\
$\mathbf{4}$ & Menarik & 9 & Formal & 14 & Sederhan & 19 & Elegan \\
$\mathbf{5}$ & Maskulin & 10 & Colorful & 15 & Tajam & 20 & Terang \\
\hline
\end{tabular}

\section{b. Sampel Specimen}

Pada penelitian ini terdapat 10 spesimen Website Jurusan, 10 spesimen ini memiliki karakteristik yang berbeda. Dari 10 calon kandidat spesimen tersebut akan dipilih 5 spesimen dengan melihat keunikan tampilan, lebar layout dan sesusai dengan program studi yang menjadi bahan penelitian. Sampel specimen disajikan pada Tabel 3.

Tabel 3. Sampel Specimen

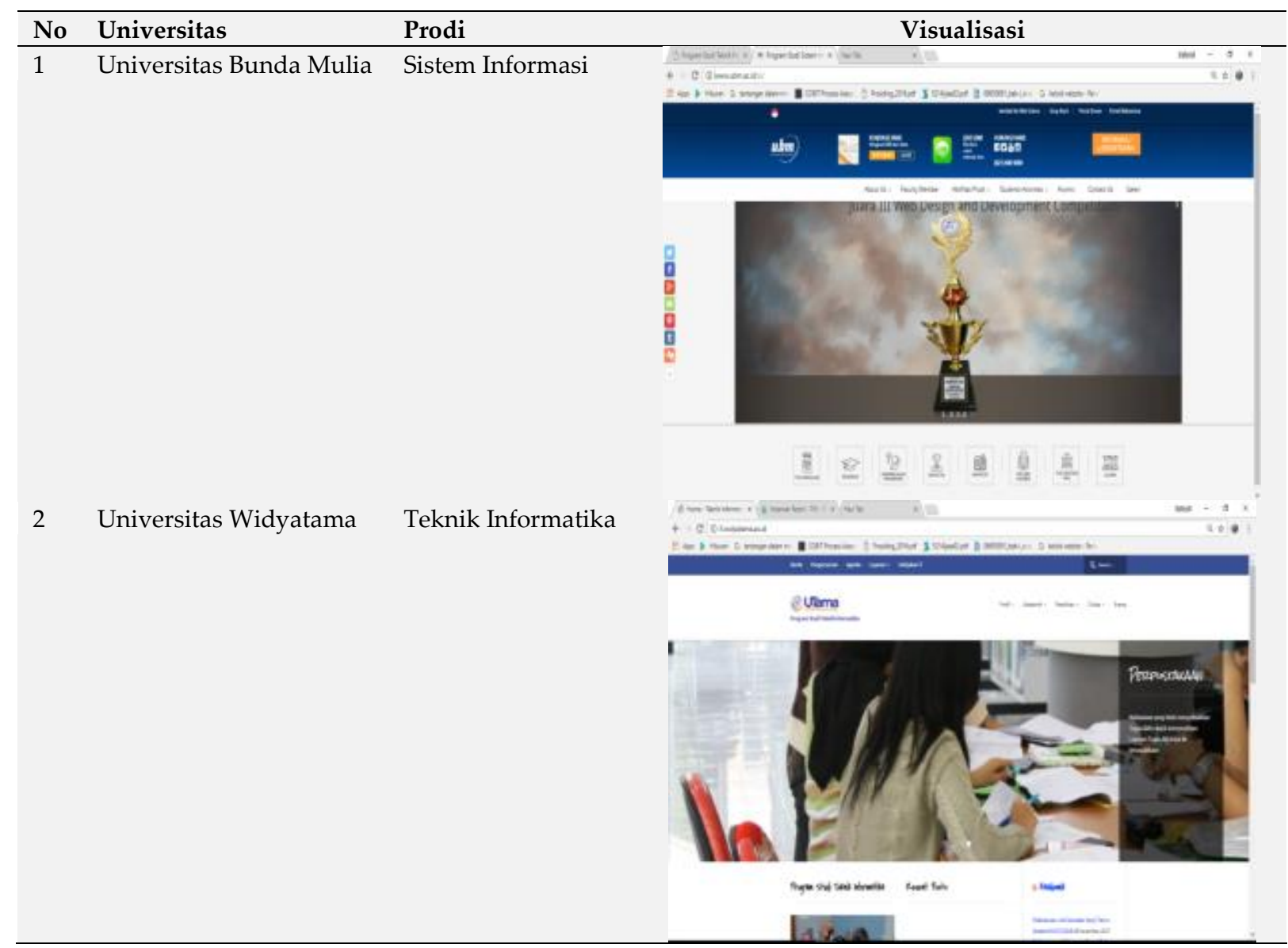




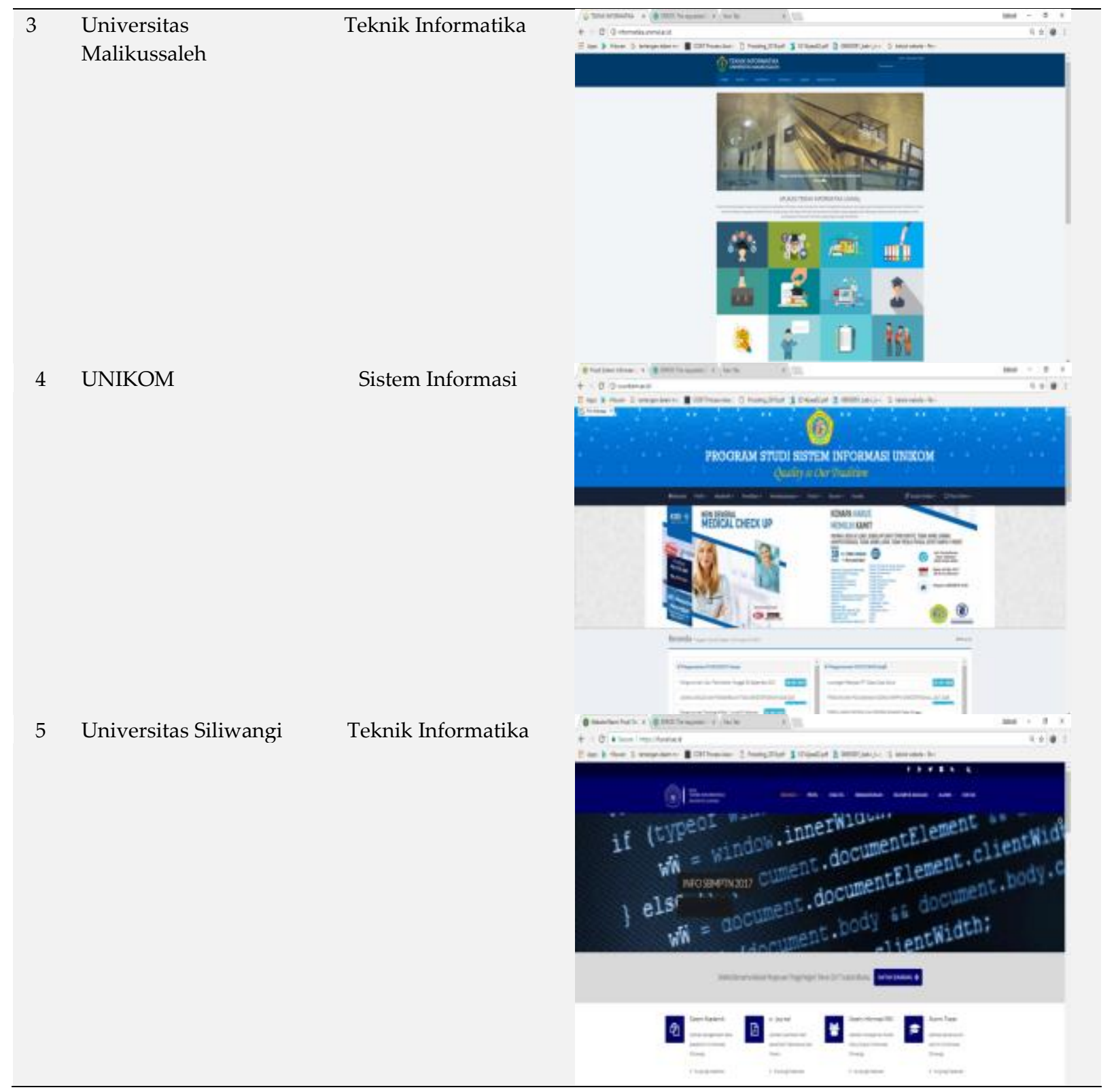

\section{c. Analisis Data dengan Metode Statisitik Multivariat}

Proses menganalisis menggunakan Factor Analysis (FA). Analisis ini dipergunakan sebagai teknik statistika dalam menyederhakan deskripsi tentang dengan cara mengurangi jumlah data pada penelitian ini adalah kansei word, karena kansei word ini dipergunakan untuk menentukan konsep baru website yang akan dirancang.

Dalam FA terdapat dua buah nilai yaitu nilai variability dan nilai cumulative. Nilai faktor 1 dan faktor 2 cukup mewakili dalam menentukan variabel mana saja yang akan menjadi acuan dalam merancang desain website. Variabel yang memiliki nilai terbesar menjadi nilai standar dalam mengurai konsep webiste, sedangkan variabel negatif menunjukkan bahwa korelasi emosi antar Kansei Words tersebut memiliki hubungan yang lemah. 
Konsep Word Berdasarkan Faktor disajikan pada Tabel 4.

Tabel 4. Konsep Word Berdasarkan Faktor

\begin{tabular}{lrlrrrrr}
\hline Kansei Word & Faktor $\mathbf{1}$ & $\begin{array}{c}\text { Kansei } \\
\text { Word }\end{array}$ & $\begin{array}{c}\text { Faktor } \\
\mathbf{2}\end{array}$ & $\begin{array}{c}\text { Kansei } \\
\text { Word }\end{array}$ & $\begin{array}{c}\text { Faktor } \\
\mathbf{1}\end{array}$ & $\begin{array}{c}\text { Kansei } \\
\text { Word }\end{array}$ & $\begin{array}{c}\text { Faktor } \\
\mathbf{2}\end{array}$ \\
\hline Rumit & -0.3500 & Sederhana & -0.9368 & Elegan & 0.7158 & Berkesan & 0.1972 \\
Sederhana & -0.3352 & Terang & -0.7498 & Menarik & 0.8813 & Unik & 0.3518 \\
Aman & -0.0756 & Cerah & -0.6662 & Serasi & 0.8893 & Modern & 0.3563 \\
Terang & 0.1457 & Elegan & -0.6506 & Kreatif & 0.9004 & Serasi & 0.3982 \\
Tajam & 0.3201 & Formal & -0.5042 & Unik & 0.9129 & Informatif & 0.6586 \\
Mewah & 0.3568 & Dinamis & -0.2914 & Modern & 0.9173 & Aman & 0.7199 \\
Maskulin & 0.4412 & Segar & -0.1294 & Dinamis & 0.9198 & Tajam & 0.7640 \\
Cerah & 0.4960 & Menarik & -0.0853 & Berkesan & 0.9345 & Mewah & 0.7873 \\
Informatif & 0.5005 & Colorful & 0.0502 & Colorful & 0.9412 & Rumit & 0.8512 \\
Formal & 0.6635 & Kreatif & 0.1938 & Segar & $\mathbf{0 . 9 7 7 3}$ & Maskulin & 0.8865 \\
\hline
\end{tabular}

Desain website yang ingin dirancang memiliki konsep emosi "segar", "colorful", "berkesan", "dinamis", "modern", "unik" dan "kreatif". Dalam mengerucutkan jumlah kansei word, maka diambil kansei word yang memiliki nilai lebih dari 0,9. Berdasarkan Tabel 4, konsep emosi "segar" memiliki nilai tertinggi pada faktor satu dan dari faktor 2 tidak ada karena nilai kurang dari 0.9, sehingga terdapat satu konsep utama yang akan dijadikan acuan dalam merancang antarmuka website.

\section{d. Menterjemahkan Data Statistik ke kedalam Elemen Desain}

Tujuan langkah ini untuk mendapatkan elemen desain yang terpengaruh dengan emosi responden dan kemudian diterjemahkan. Data yang dimanfaatkan pada PLS terdiri dari tiga elemen:

1) Variabel Independent ( $\mathrm{x}$ ), yaitu elemen desain yang diterjemahkan ke dalam dummy variable.

Klasifikasi elemen desain pada specimen website diberi nilai 1 yang artinya elemen desain tersebut terpilih dan kolom kosong diberi nilai 0 yang artinya elemen desain tersebut tidak terpilih.

2) Variabel Dependent (y), yaitu hasil rekapitulasi rata-rata 20 emosi dari 30 responden.

3) Lima spesimen website.

Dummy variable elemen desain disajikan pada Tabel 5. 
Tabel 5. Dummy Variable Elemen Desain

\begin{tabular}{|c|c|c|c|c|c|c|c|c|c|c|c|c|}
\hline \multirow{3}{*}{ ID } & \multirow{2}{*}{\multicolumn{2}{|c|}{$\begin{array}{c}\text { Background } \\
\text { Warna }\end{array}$}} & \multicolumn{9}{|c|}{ Header } & \multirow{3}{*}{$\begin{array}{c}\cdots \\
\cdots \\
\cdots\end{array}$} \\
\hline & & & \multicolumn{3}{|c|}{ Background Color } & \multicolumn{2}{|c|}{$\begin{array}{c}\text { Background } \\
\text { Image } \\
\end{array}$} & \multicolumn{2}{|c|}{ Menu } & \multicolumn{2}{|c|}{ Posisi logo } & \\
\hline & $\begin{array}{l}\text { Abu- } \\
\text { abu }\end{array}$ & Putih & Biru & Putih & $\begin{array}{c}\text { Gradien } \\
\text { warna }\end{array}$ & Ada & Tidak & Ada & Tidak & Kiri & Tengah & \\
\hline Spesimen 1 & 0 & 1 & 0 & 0 & 1 & 0 & 1 & 0 & 1 & 1 & 0 & $\ldots$ \\
\hline Spesimen 2 & 0 & 1 & 0 & 1 & 0 & 0 & 1 & 1 & 0 & 1 & 0 & $\ldots$ \\
\hline Spesimen 3 & 1 & 0 & 1 & 0 & 0 & 0 & 1 & 0 & 1 & 1 & 0 & $\ldots$ \\
\hline Spesimen 4 & 1 & 0 & 0 & 0 & 0 & 1 & 0 & 0 & 1 & 0 & 1 & $\ldots$ \\
\hline Spesimen 5 & 0 & 1 & 1 & 0 & 0 & 0 & 1 & 1 & 0 & 1 & 0 & $\ldots$ \\
\hline
\end{tabular}

Jika semua elemen PLS telah dibuat, Data dummy variabel kemudian diolah menggunakan PLS Regression yang terdapat pada software XL Stat 2014 dengan melibatkan data rata-rata hasil kuisioner dan rata-rata lima spesimen. Hasilnya analisis PLS disajikan pada Tabel 6.

Tabel 6. Hasil Analisis PLS

\begin{tabular}{llllllll}
\hline \multicolumn{1}{c}{ Variable } & Segar & Serasi & Kreatif & Menarik & Maskulin & Aman & $\ldots$ \\
\hline Background warna Abu-abu & 0.0469 & 0.0552 & 0.0668 & 0.0442 & 0.0197 & 0.0069 & $\ldots$ \\
Background warna Putih & -0.0469 & -0.0552 & -0.0668 & -0.0442 & -0.0197 & -0.0069 & $\ldots$ \\
Header Background-Color Biru & 0.0198 & 0.0321 & 0.0822 & 0.0457 & 0.0221 & 0.0001 & $\ldots$ \\
Header Background-Color Putih & -0.0021 & -0.0287 & -0.0505 & -0.0185 & -0.0310 & -0.0122 & $\ldots$ \\
Header Background-Color Gradien & -0.0074 & -0.0179 & -0.0356 & -0.0175 & -0.0146 & -0.0038 & $\ldots$ \\
Header Background-Image Ada & -0.0201 & -0.0014 & -0.0372 & -0.0326 & 0.0124 & 0.0158 & $\ldots$ \\
Header Background-Image Tidak & 0.0201 & 0.0014 & 0.0372 & 0.0326 & -0.0124 & -0.0158 & $\ldots$ \\
Header Menu Ada & -0.0420 & -0.0433 & -0.0430 & -0.0326 & -0.0100 & -0.0044 & $\ldots$ \\
Header Menu Ada & 0.0420 & 0.0433 & 0.0430 & 0.0326 & 0.0100 & 0.0044 & $\ldots$ \\
Header Posisi Logo Kiri & 0.0201 & 0.0014 & 0.0372 & 0.0326 & -0.0124 & -0.0158 & $\ldots$ \\
Header Posisi Logo Tengah & -0.0201 & -0.0014 & -0.0372 & -0.0326 & 0.0124 & 0.0158 & $\ldots$ \\
\multicolumn{1}{c}{$\ldots$} & $\ldots$ & $\ldots$ & $\ldots$ & $\ldots$ & $\ldots$ & $\ldots$ & $\ldots$ \\
\hline
\end{tabular}

e. Pengintegrasian Webqual 4.0 dengan Metode Kano

Sebelum mengintegrasi, langkah awal adalah mengidentifikasi atribut-atribut layanan yang perlu dievaluasi menurut model Webqual 4.0 yang terdiri dari dari dimensi Webqual yang terdiri dari Kualitas Informasi (Information Quality), Layanan Interaksi (Interaction Service) dan Kualitas Penggunan (Usability Quality). Setelah mengetahui fakta tentang layanan pada, untuk mendapatkan informasi dari data kuisioner dikategori antara lain one dimensional, attractive, must-be, indifferent, reverse, questionable dengan bantuan metode kano. Atribut pada Webqual dinilai dengan metode kano [6]. 
Penilaian tersebut dikelompokan berdasarkan rumus Walden. Setelah dikelompok tersebut maka dapat diketahui nilai atribut untuk kategori "Penting" dan "Kinerja" dari kedua kategori tersebut maka akan diketahui kesenjangan (Gap) untuk masing-masing atribut.

Dalam proses mencari nilai memanfaatkan perhitungan model Walden, rumusnya sebagai berikut:

a. Jumlah (one dimensional + attractive + must-be) $>($ indifferent + reverse + questionable $)$ maka grade dari nilai paling maksimum (one dimensional + attractive + must-be).

b. Jumlah (one dimensional + attractive + must-be $)<($ indifferent + reverse + questionable $)$ maka grade dari nilai paling maksimum (indifferent + reverse + questionable).

c. Jumlah (one dimensional + attractive + must-be $)=($ indifferent + reverse + questionable $)$ maka grade dari nilai paling maksimum diantara (one dimensional, attractive, must-be dan indifferent, reverse, questionable).

Gap antara kepentingan dan kinerja disajikan pada Tabel 7.

Tabel 7. Gap antara Kepentingan dan Kinerja

\begin{tabular}{|c|c|c|c|c|}
\hline No & Atribut Layanan & Kepentingan & Kinerja & Gap \\
\hline \multicolumn{5}{|c|}{ Usability } \\
\hline 1 & Web ini mudah dioperasikan & 3.867 & 3.667 & -0.2 \\
\hline 2 & Interaksi dengan web jelas dan mudah dipahami & 3.933 & 3.4 & -0.533 \\
\hline 3 & Mudah untuk menemukan menu-menu didalam web & 4.233 & 3.767 & -0.466 \\
\hline 4 & Web ini memiliki kemudahan dalam navigasi & 4.067 & 3.433 & -0.634 \\
\hline 5 & Alamat web mudah diakses & 4.333 & 4.1 & -0.233 \\
\hline 6 & Penyusunan tata letak informasi dalam web tepat & 3.567 & 2.967 & -0.6 \\
\hline 7 & Website memiliki tampilan menarik & 3.433 & 2.767 & -0.666 \\
\hline 8 & Penyajian informasi memenuhi kebutuhan user & 3.967 & 3.5 & -0.467 \\
\hline 9 & Komponen pada web sesuai kebutuhan user & 3.867 & 3.4 & -0.467 \\
\hline \multicolumn{5}{|c|}{ Information Quality } \\
\hline 10 & Informasi yang tersedia pada web akurat & 4.2 & 3.767 & -0.433 \\
\hline 11 & Informasi yang tersaji pada web dapat dipercaya & 4.4 & 3.8 & -0.6 \\
\hline 12 & Penyajian informasi pada web selalu up to date & 4 & 3.333 & -0.667 \\
\hline 13 & Informasi yang disajikan relevan dengan bidang studi user & 4.033 & 3.767 & -0.266 \\
\hline 14 & Teks pada web dapat dibaca dengan jelas & 3.933 & 3.767 & -0.166 \\
\hline 15 & Gambar dalam web dapat dilihat jelas & 3.9 & 3.367 & -0.533 \\
\hline 16 & Web menyajikan informasi yang detail & 3.833 & 3.633 & -0.2 \\
\hline 17 & Informasi dalam web ini disajikan dengan format yang sesuai & 3.9 & 3.633 & -0.267 \\
\hline \multicolumn{5}{|c|}{ Service Interaction } \\
\hline 18 & Secara keseluruhan penggunaan komponen web tidak mengalami error & 4.267 & 3.6 & -0.667 \\
\hline 19 & File yang dapat diunduh dari web aman dari virus & 4.133 & 3.8 & -0.333 \\
\hline
\end{tabular}

Tabel 7 merupakan hasil integrasi metode Kano dengan Webqual 4.0, menghasilkan nilai untuk Gap, jika Gap bernilai negatif mengartikan website mahasiswa belum memenuhi kepentingan mahasiswa . 


\subsection{Hasil}

Rekomendasi konsep desain antarmuka website berdasarkan emosi responden. Rekomendasi konsep desain yang dibuat adalah konsep desain yang sesuai dengan sasaran emosi, artinya konsep desain tersebut dianggap menyenangkan oleh responden. Data yang menjadi acuan dalam membuat konsep wesbite adalah data yang memiliki nilai yang tertinggi. Hal ini tidak mengartikan, jika nilai data yang kurang tidak dibutuhkan, tetapi menjadi faktor tambahan dalam menyempurnakan website. Rekomendasi tampilan website disajikan pada Tabel

8.

Tabel 8. Rekomendasi Tampilan Website

\begin{tabular}{|c|c|c|c|c|}
\hline \multirow{2}{*}{ No } & \multicolumn{2}{|l|}{ Konsep Emosi : Segar } & \multicolumn{2}{|c|}{ Range Rata-Rata } \\
\hline & Kategori & Koefisien & Range & Konsep Desain \\
\hline 1 & Background Warna & 0.1138 & 0.2276 & $\mathrm{Abu}-\mathrm{Abu}$ \\
\hline 2 & Header Background-Color & 0.0479 & 0.0625 & Biru \\
\hline 3 & Header Background-Image & 0.0399 & 0.0798 & Tidak Ada \\
\hline 4 & Header Menu & 0.1019 & 0.2038 & Tidak Ada \\
\hline 5 & Header Posisi Logo & 0.0399 & 0.0798 & Kiri \\
\hline 6 & Navigasi & 0.0445 & 0.089 & Ada \\
\hline 7 & Menu Posisi & 0.0399 & 0.0798 & Atas \\
\hline 8 & Menu Warna Text & 0.1793 & 0.3103 & Biru \\
\hline 9 & Body Ukuran Huruf & 0.1345 & 0.2551 & $14 \mathrm{px}$ \\
\hline 10 & Body Jenis Huruf & 0.0361 & 0.0722 & Arial \\
\hline 11 & Footer Konten & 0.1138 & 0.0992 & Link Medsos \\
\hline 12 & Footer Background Color & 0.1138 & 0.2344 & Biru \\
\hline
\end{tabular}

Memetakan hasil pengkategorian untuk setiap atribut dengan metode kano. Pemetaan prioritas atribut layanan disajikan pada Tabel 9.

Tabel 9. Pemetaan Prioritas Atribut Layanan

\begin{tabular}{|c|c|c|c|c|}
\hline No & Atribut Layanan & Kategori Gap & Grade Kano & Prioritas \\
\hline \multicolumn{5}{|c|}{ Usability } \\
\hline 1 & Web ini mudah dioperasikan & UP & M & U1 \\
\hline 2 & Interaksi dengan web jelas dan mudah dipahami & HOLD & I & $\mathrm{H} 2$ \\
\hline 3 & Mudah untuk menemukan menu-menu didalam web & HOLD & I & $\mathrm{H} 2$ \\
\hline 4 & Web ini memiliki kemudahan dalam navigasi & HOLD & I & $\mathrm{H} 2$ \\
\hline 5 & Alamat web mudah diakses & UP & $\mathrm{O}$ & $\mathrm{U} 3$ \\
\hline 6 & Penyusunan tata letak informasi dalam web tepat & HOLD & I & $\mathrm{H} 2$ \\
\hline 7 & Web memiliki tampilan menarik & HOLD & I & $\mathrm{H} 2$ \\
\hline 8 & Penyajian informasi memenuhi kebutuhan user & HOLD & I & $\mathrm{H} 2$ \\
\hline 9 & Komponen pada web sesuai kebutuhan $u$ ser & HOLD & I & $\mathrm{H} 2$ \\
\hline \multicolumn{5}{|c|}{ Information Quality } \\
\hline 10 & Informasi yang tersedia pada web akurat & UP & M & U1 \\
\hline 11 & Informasi yang tersaji pada web dapat dipercaya & HOLD & M & $\mathrm{H} 1$ \\
\hline 12 & Penyajian informasi pada web selalu up to date & HOLD & M & $\mathrm{H} 1$ \\
\hline 13 & Informasi yang disajikan relevan dengan bidang studi user & UP & I & $\mathrm{U} 2$ \\
\hline 14 & Teks pada web dapat dibaca dengan jelas & UP & $\mathrm{O}$ & $\mathrm{U} 3$ \\
\hline 15 & Gambar dalam web dapat dilihat jelas & HOLD & M & $\mathrm{H} 1$ \\
\hline 16 & Web menyajikan informasi yang detail & UP & I & $\mathrm{U} 2$ \\
\hline 17 & Informasi dalam web ini disajikan dengan format yang sesuai & UP & I & $\mathrm{U} 2$ \\
\hline \multicolumn{5}{|c|}{ Service Interaction } \\
\hline 18 & Secara keseluruhan penggunaan komponen web tidak mengalami error & HOLD & I & $\mathrm{H} 2$ \\
\hline 19 & File yang dapat diunduh dari web aman dari virus & UP & M & U1 \\
\hline
\end{tabular}




\section{KESIMPULAN}

Pada bagian kajian konsep website yang memanfaatkan metode kansei engineering merekomendasi untuk melibatkan emosional pengguna dalam membuat konsep website. Rekomendari yang dihasilkan berupa matriks berisi elemen-elemen desain website yang berdasarkan konsep emosi "segar". Pada evaluasi layanan website mahasiswa menggunakan model Webqual 4.0 dan Kano dapat menunjukan kategori dari atribut dari dimensi Information Quality, Interaction Service, Usability Quality yang perlu ditingkatkan dan yang dipertahakan berdasarkan prioritas masing-masing. Jumlah atribut layanan yang termasuk kedalam prioritas U1 (ditingkatkan prioritas pertama) sebanyak 3 atribut, prioritas U2 (ditingkatkan prioritas kedua) 5 atribut, prioritas U3 (ditingkatkan prioritas ketiga) 2 atribut, prioritas H1 (dipertahankan prioritas pertama) 4 atribut, prioritas H2 (dipertahankan prioritas kedua) 11 atribut.

\section{REFERENSI}

[1] Restama, M. (2014). Efektifitas Akademik Sebagai Saran Penyampaian Informasi Akademik Bagi Mahasiswa Universitas Riau. Jom FISIP Volumen 1 No.2 , 1-15

[2] Dauni, P. (2015). Implementasi Kansei Engineering Terhadap Desain Antarmuka Website Sistem Informasi Akademik Berbasis Online. Bandung: Sekolah Tinggi Manajemen Informatika dan Komputer LIKMI.

[3] Ramadhan, T. (2016). Implementasi Kansei Engineering dalam Desain Tampilan Website Perguruan Tinggi (Studi Kasus : STIEB Perdana Mandiri Purwakarta). Bandung: Sekolah TInggi Manajemen Informatika dan Komputer LIKMI.

[4] Wicaksono, F. (2016). Penerapan Kansei Engineering pada Rancangan Antarmuka ELearning Berbasis Web. Seminar Nasional Teknologi Informasi dan Multimedia , 13-18.

[5] Ginanjar, A. (2016). Implementasi Kansei Engineering dalam Desain Tampilan Website Mobile Berita Informasi Orang Tua dan Anak (Studi Kasus : www.buahatiku.com) Bandung: Sekolah Tinggi Manajemen Informatika dan Komputer LIKMI.

[6] Hadiana, A. (2015). Pemanfataan Kansei Engineering dalam Pengembangan Sistem Informasi. Infotech Journal , 32-35.

[7] Muhaemin, M. (2016). Implementasi Kansei Engineering dalam Desain Website Profile Perguruan Tinggi (Studi Kasus:STMIK Sumedang). Jurnal Informan's , 32-39. 
[8] Jaelani, I. (2015). Penerpan Metode Kano Berdimensi Servqual dalam Menganalisis Kualitas Layanan Sistem Informasi Akademik Terhadap Kepuasan Penguna (Studi Kasus SIMAK STT. Wastukancana Purwakarta). Bandung: Sekolah Tinggi Manajemen Informatika dan Komputer LIKMI.

[9] Ramdon, E. (2013). Adopsi Metode Kano untuk Kesuksesan dan Ketidaksuksesan Sistem Informasi. Bandung: Institut Teknologi Bandung. 